\title{
BIOCHEMICAL RESPONSES OF TWO ERYTHRINIDAE FISH TO ENVIRONMENTAL AMMONIA
}

\author{
MORAES, G., ${ }^{1}$ POLEZ, V. L. P. ${ }^{1}$ and IWAMA, G. K. ${ }^{2}$ \\ ${ }^{1}$ Departamento de Genética e Evolução, Universidade Federal de São Carlos, Rod. Washington Luís, km 235, \\ C.P. 676, CEP 13560-905, São Carlos, SP, Brazil \\ ${ }^{2}$ National Research Council Canada, 1411, Oxford, St. Halifax, N.S. B3H 3Z1, Canada \\ Correspondence to: Gilberto Moraes, Departamento de Genética e Evolução, Universidade Federal de São Carlos, \\ Rod. Washington Luís, km 235, C.P. 676, CEP 13560-905, São Carlos, SP, Brazil, \\ e-mail: gil@ power.ufscar.br \\ Received May 10, 2002 - Accepted February 26, 2003 — Distributed February 29, 2004
}

(With 2 figures)

\begin{abstract}
The non-ionized form of ammonia is very toxic to many aquatic species. It is especially important in several aspects of fish biology. A large range of organismal strategies for coping with environmental stressors is usually observed in living organisms. Among those, the responses for managing chemical stressors are well studied. The present work compares biochemical responses of two evolutionarily close species, Hoplias malabaricus and Hoplerythrinus unitaeniatus, exposed to environmental ammonia. Adult fish were submitted to $1.0 \mathrm{mg} / \mathrm{L}$ of ammonium chloride for 24 hours, and plasma ammonia and urea levels were determined. The activities of OUC enzymes OCT and ARG, and the accessory enzyme GS, were quantified in liver extract and are expressed below in $\mu \mathrm{mol} / \mathrm{min} / \mathrm{mg}$ of wet tissue. Increases in OUC enzymes (GS from 1.14 to 2.43 , OCT from 0.81 to 1.72 , and ARG from 3.15 to 4.23 ), plasma ammonia (from 0.95 to $1.42 \mathrm{mmol} / \mathrm{L}$ ), and plasma urea (from 0.82 to $1.53 \mathrm{mmol} / \mathrm{L}$ ) were observed ( $<$ 0.05) in $H$. malabaricus exposed to $1 \mathrm{mg} / \mathrm{L}$ of ammonia chloride. The GS in $H$. unitaeniatus increased from 1.43 to 1.84 , however the OCT, ARG, and plasma urea from $H$. unitaeniatus did not change. These data indicate that each species responds differently to the same environmental stressor.
\end{abstract}

Key words: Hoplias malabaricus, Hoplerythrinus unitaeniatus, ammonia, biochemical adaptation, fish, Ornithine-urea cycle enzymes.

\section{RESUMO}

\section{Respostas bioquímicas de duas espécies de Erythrinidae à amônia ambiental}

A forma não ionizada da amônia é muito tóxica a vários organismos aquáticos, sendo particularmente importante em muitos aspectos da biologia dos peixes. Um amplo grupo de estratégias para enfrentar os estressores ambientais pode ser observado nos organismos vivos. Dentre estas, as respostas aos estressores químicos são bem estudadas. O presente trabalho compara respostas bioquímicas de duas espécies evolutivamente próximas Hoplias malabaricus e Hoplerythrinus unitaeniatus, expostas à amônia ambiental. Peixes adultos foram submetidos a $1.0 \mathrm{mg} / \mathrm{L}$ de cloreto de amônio por 24 horas e foram determinados os níveis plasmáticos de amônia e uréia. As atividades das enzimas do COU, OCT e ARG e a enzima acessória GS foram quantificadas em extrato de fígado e são expressas em $\mu \mathrm{mol} / \mathrm{min} / \mathrm{mg}$ de tecido úmido. Foi observado em $\mathrm{H}$. malabaricus, exposto a $1,0 \mathrm{mg} / \mathrm{L}$ de cloreto de amônio, aumento $(\mathrm{p}<0,05)$ nas enzimas: GS, de 1,14 para 2,43; OCT, de 0,81 para 1,72; ARG, de 3,15 para 4,23; na amônia plasmática, de 0,95 para $1,42 \mathrm{mmol} / \mathrm{L}$, e na uréia plasmática, de 0,82 para 1,53. A GS de $H$. malabaricus aumentou de 1,43 para 1,84, todavia, OCT, ARG e uréia plasmática não variaram. Esses dados mostram que ambas as espécies, taxonomicamente próximas, respondem distintamente ao mesmo estressor ambiental.

Palavras-chave: Hoplias malabaricus, Hoplerythrinus unitaeniatus, amônia, adaptação bioquímica, peixe, enzimas do ciclo Ornitina-urea. 


\begin{abstract}
ABBREVIATIONS
ARG (arginino hydrolase), EDTA (ethylenediaminetetracetic acid), GS (glutamine synthetase), Ki (inhibition constant), $\mathrm{K}_{\mathrm{m}}$ (Michaelis-Menten constant), MS222 (3-aminobemzoic acid ethyl ester), HEPES (N-2-hydroxymethyl-piperazine-N'-2-ethanesulfonic acid), National Center of Research on Tropical Fish CEPTA-IBAMA, OCT (ornithine carbamoyl transferase), OUC (ornithine urea cycle), PCA (perchloric acid), ppm (parts per million), TCA (trichloroacetic acid), TRIS (Tris[hydroxymethyl] aminomethane).
\end{abstract}

\section{INTRODUCTION}

Several physical and chemical components of freshwater environments often fluctuate, producing changes to which organisms within the water must accommodate. Ammonia is a chemical example. However, if high content of ammonia is present, as is usual in eutrophic water environments, it works as a stressor (Alabaster \& Lloyd, 1980). Stressing components in the medium demand adaptive responses from the organism. A large group of responses constantly stands ready to face ambient oscillations in order to preserve organism homeostasis. Those responses consist of a range of morphological (Val \& Almeida-Val, 1995) or physiological and molecular adjustments (Hochachka $\&$ Somero, 1973, 1984), and determine the required biochemical adaptations.

Environmental ammonia concentration is dependent on temperatures ranging from 0.0083 to 89 percent (Emerson et al., 1975). Two chemical forms exist, $\mathrm{NH}_{3}$ and $\mathrm{NH}_{4}^{+}$and the ratio of both is $\mathrm{pH}$ dependent. In spite of ammonia being a nutrient in eutrophic cells, most of vertebrates exhibit a low tolerance to this compound. High ammonia concentrations are a limiting factor in farm fishing because such concentrations cause growth rate decrease, plasma cortisol increase, gill damage, impairment of gas diffusion, and excessive mucus production (Smart, 1976; Tomasso et al., 1981; Spotte \& Anderson, 1989; Wright, 1995). Sensitivity of many freshwater teleosts to increasing external ammonia concentrations can culminate in death (Olson \& Fromm, 1971; Dabrowska \& Wlasow, 1986).
Toxicity through increase of external ammonia comes with corresponding plasma level enhancement. Among the ammonia detoxification strategies, glutamine formation from glutamate and the urea synthesis from glutamine and aspartate (Mommsen, \& Walsh, 1989, 1992; Walsh, 1997; McKenzie et al., 1999) are relevant. Glutamine synthesis occurs independently of urea formation. However, fish urea synthesis is dependent on glutamine as substrate. Regulation of these biochemical processes is done in many ways, such as gene control, enzyme compartmentalization, metabolite concentration, and kinetic characteristics of enzymes. In this study of OUC enzymes, characteristics correlated to environmental pressures provide a path to understanding relevant aspects of regulatory mechanisms in biochemical processes.

Hoplias malabaricus (traíra) and Hoplerythrinus unitaeniatus (jeju) inhabit warm and lentic waters exposed to several biological, physical, and chemical changes (Godoy, 1975; Nelson, 1984). It should be expected that closely related species are likely to use similar strategies to cope with environmental changes. Our question is if evolutionary closely species, usually sharing the same environment, display similar strategies in coping with environmental stressors. We exposed two closely related teleost species, $H$. malabaricus and $H$. Unitaeniatus, to increasing environmental ammonia and observed the nitrogenous excretory pattern.

\section{MATERIAL AND METHODS}

\section{Fish collection and maintenance}

Adult fish of the species H. malabaricus and $H$. unitaeniatus were collected from shallow ponds on the shore of Mogi-Guaçu River, São Paulo State, Brazil and brought to the aquaculture facilities of the CEPTA-IBAMA in Pirassununga. The experiments were performed in January and February. Twelve jeju, weighing $20 \pm 5 \mathrm{~g}$ (means $\pm \mathrm{SD}$ ), and 12 traira weighing $90 \pm 10 \mathrm{~g}$ (means $\pm \mathrm{SD}$ ), were kept unfed in $500 \mathrm{~L}$ boxes for 14 days before the experiments. Aerated water (7.5 ppm of oxygen) was pumped from the Mogi-Guaçu River into the laboratory, and the water quality was the same for all experiments. Water temperature was kept constant at $25 \pm 2^{\circ} \mathrm{C}$, and the $\mathrm{pH}$ was monitored and kept at $7.0 \pm 0.5$. 


\section{Experimental design}

The specimens of jeju and traíra were transferred to four aquaria of $60 \mathrm{~L}$ (six fish per aquarium). Two aquaria, one per species, were kept undisturbed (control). Ammonia chloride was added to the others to the final concentration of $1.0 \mathrm{mg} /$ L. Water hardness was $40 \mathrm{mg} \mathrm{CaCO}_{3} / \mathrm{L}$, alkalinity was $21 \mathrm{mg} / \mathrm{L}$, and $\mathrm{pH}$ was constantly monitored and kept at $7.0 \pm 0.2$ throughout the experiment. Concentrations of $\mathrm{NO}_{2}^{-}$and $\mathrm{Cl}^{-}$were inconspicuous. The fish were kept throughout the experiment in a static system (without water renewal). After $24 \mathrm{~h}$ they were transferred to a single $3.0 \mathrm{~L}$ box containing $0.27 \mathrm{~g} / \mathrm{L}$ MS222, $\mathrm{pH} 7.0 \pm 2$. Right after the anesthetic effect, a blood sample was taken from the caudal vein in $1.0 \mathrm{ml}$ syringes and placed in heparinized $2.0 \mathrm{ml}$ polypropylene tubes. The blood samples were centrifuged at $9,000 \mathrm{~g}$ for $5 \mathrm{~min}$. The plasma was stored at $-20^{\circ} \mathrm{C}$ for posterior biochemical analysis. Following the blood collection, the fish were killed by pinching the spinal cord. The liver was excised and immediately frozen in liquid nitrogen for later biochemical analysis.

\section{Tissue extract}

The liver samples were homogenized under ice-cold conditions at the ratio of 1:6 (w/v) in homogenization buffer $(0.01 \mathrm{M}$ Tris, $0.02 \mathrm{M} \mathrm{Na}$ phosphate, $0.01 \mathrm{M}$ glycine, EDTA $0.5 \mathrm{mM} \mathrm{pH} 7.0$, into glycerol $\mathrm{v} / \mathrm{v}$ ) in a glass vessel with a motordriven Teflon pestle. The homogenate was centrifuged at $3,000 \times \mathrm{g}$ at $4^{\circ} \mathrm{C}$ for $15 \mathrm{~min}$ and the pellet was discarded. The supernatant was centrifuged at $8,000 \times \mathrm{g}$ at $4{ }^{\circ} \mathrm{C}$ for $20 \mathrm{~min}$ and used as a soluble enzyme source (crude homogenate).

\section{Perchloric acid plasma extract}

The plasma, obtained by blood centrifugation at $9,000 \times \mathrm{G}$ for $5 \mathrm{~min}$, was treated with $0.6 \mathrm{~N}$ PCA $1: 10(\mathrm{v} / \mathrm{v})$. The samples were neutralized with $6.0 \mathrm{~N}$ $\mathrm{KHCO}_{3}$ and the precipitate was removed by centrifugation. Urea (Rahmatullah \& Boyde, 1980), ammonia (Gentzkow \& Mansen, 1942), and uric acid (Henry et al., 1957) were determined in the supernatant.

\section{Ornithine carbamoyl transferase (OCT)}

The OCT enzyme activity was assayed in 1.5 $\mathrm{ml}$ of reaction mixture containing, to final concentration, $50 \mathrm{mM}$ of HEPES (pH 8.0), $10 \mathrm{mM}$ of ornithine, $10 \mathrm{mM}$ of carbamoyl phosphate, and suitable enzyme aliquot (Boyde \& Rahmatullah, 1980). The samples were incubated at $25^{\circ} \mathrm{C}$ for 30 min and the reaction was stopped by $70 \%$ TCA addition. The reaction mixtures were centrifuged at $12,000 \times \mathrm{G}$ for $2 \mathrm{~min}$. Citrulline, the enzyme end product, was colorimetrically determined at $464 \mathrm{~nm}$.

\section{Glutamine synthetase (GS)}

The GS enzyme activity was assayed by $\gamma$ glutamyl hydroxamate formation modified (Vorhaben et al., 1973). The incubation mixture, containing to final concentration $50 \mathrm{mM}$ HEPES $\mathrm{pH} 7.0,60$ $\mathrm{mM}$ glutamine, $15 \mathrm{mM}$ hydroxyl amine, $0.4 \mathrm{mM}$ ADP, $20 \mathrm{mM} \mathrm{NaAsO}_{4}$, and $3 \mathrm{mM} \mathrm{MnCl}_{2}$ was brought to a final volume of $1.5 \mathrm{ml}$ with a suitable amount of enzyme. After incubation for $60 \mathrm{~min}$ at $25^{\circ} \mathrm{C}$, the reaction was stopped with $300 \mu \mathrm{L}$ of ferricchloride-reagent and centrifuged at 7,000 $\times \mathrm{G}$ for $1 \mathrm{~min}$ at $5^{\circ} \mathrm{C}$. The reaction product $\gamma$-glutamyl hydroxamate was directly estimated in the supernatant at $560 \mathrm{~nm}$.

\section{Arginino hydrolase (ARG)}

The ARG activity was assayed by urea determination from the arginine hydrolysis (Rahmatullah \& Boyde, 1980). The reaction mixture containing $50 \mathrm{mM}$ glycine (pH 10.0 for traira assays or $\mathrm{pH} 9.5$ for jeju), $278 \mathrm{mM}$ arginine, and $10 \mathrm{mM}$ $\mathrm{MnCl}_{2}$ was brought to final volume of $1.5 \mathrm{ml}$ with appropriate enzyme aliquot. The reaction was stopped with $70 \%$ TCA, centrifuged at 7,000 $\times \mathrm{G}$ for $1 \mathrm{~min}$, and urea was colorimetrically determined at $460 \mathrm{~nm}$.

\section{Enzyme optimization}

The enzyme reaction of ARG and OCT were optimized for $\mathrm{pH}$ and temperature. The $\mathrm{pH}$ range assayed varied from 4.0 to 11.0 for both enzymes, and the buffer systems citrate, TRIS, HEPES, glycine, and glycil-glycine were assayed. The best buffer and the optimum $\mathrm{pH}$ are depicted above in the enzyme assay procedures. The optimum temperature assayed was from 20 to $85^{\circ} \mathrm{C}$. The reactions were carried out under a water-bath, observing temperature intervals of approximately $10^{\circ} \mathrm{C}$, with the best buffer system at the optimum $\mathrm{pH}$. Considering the elevated optimal temperature, the values of $\mathrm{K}_{\mathrm{m}}$ for $\mathrm{ARG}$ and OCT were determined at room temperature $\left(25^{\circ} \mathrm{C}\right)$. 


\section{Chemicals}

All chemicals were analytical grade purchased from Sigma Chemical Co., or Merck. The MS222 was from Sandoz.

\section{Statistics}

Statistical tests were performed using the Mann Whitney test. The significance level was set at $\mathrm{p} \leq$ 0.05 . The Pearson correlation coefficient was used for some parameters and the critical values for (r) were set at $95 \%$.

\section{RESULTS}

Traíra exposed to ammonia did not show any behavioral change. However, jeju exhibited elevated activity in response to ammonia exposure. Enzyme kinetics of ARG for both species were similar, depicting a Michaellis-Menten profile (Fig. 1A and B). The $\mathrm{V}_{\text {max }}$ were $0.023 \mu \mathrm{mol} / \mathrm{min} \mathrm{mg}$ of wet tissue for traíra, and $0.039 \mu \mathrm{mol} / \mathrm{min} \mathrm{mg}$ of wet tissue for jeju. The carbamoyl phosphate saturation curves for OCT of traira and jeju were similar and a typical Michaelis-Menten kinetic was observed for both. However, OCT from traira was inhibited with $3 \mathrm{mM}$ ornithine. The same effect for jeju was not evident but a trend for inhibition was observed. The OCT from both species were inhibited by inorganic phosphate (Fig. 2A and B). The kinetic parameters of OCT and ARG from both species are shown in Table 1. Plasma ammonia of traíra and jeju exposed to environmental ammonia increased significantly but increase of urea was observed only in traíra (Table 2). All liver OUC enzymes from traíra increased under ammonia exposure whereas only GS increased in jeju (Table 2). Changes in plasma uric acid were detected in neither species and the concentration was very low (traces).

\section{DISCUSSION}

Both species, traíra and jeju, probably arose in the Jurassic (Godoy, 1975), and are presently living in similar environments (Nelson, 1984). Traíra and jeju usually feed on fish and insects respectively, which are both rich in protein. This kind of rich protein nourishment was proposed to induce changes in nitrogen catabolism (Cvancara, 1969). Among the OUC enzymes, ARG activity is supposed to increase under rich protein diets supporting nitrogen excretion (Cvancara, 1969). The compartimentalization of OUC enzymes of erythrinidae were previously studied by Polez $e t$ al. (1998) under usual environmental conditions. However, the ammonia exposure induced differential changes in the enzyme kinetic characteristics. This suggests distinct roles of OUC enzymes for the species in coping with ammonia.

The enzyme kinetics of ARG and OCT presented interesting features. The ARG characteristics for both species appear very similar. In spite of the hypothesis supporting a direct relationship between ARG activity and dietary protein level (Cvancara, 1969), a large range of enzyme activities with very similar values for distinct species could be observed. Jeju and traíra feeding high protein diets should result in increase of amino nitrogen wasting through ARG.

TABLE 1

Kinetic parameters of liver ornithine carbamoyl transferase (OCT) and arginine hydrolase (ARG) from $H$. malabaricus and $H$. unitaeniatus exposed to $1.0 \mathrm{mg} / \mathrm{L}$ of ammonia.

\begin{tabular}{|c|c|c|c|c|}
\hline \multirow[b]{2}{*}{ Parameter } & \multicolumn{2}{|c|}{ OCT } & \multicolumn{2}{|c|}{ ARG } \\
\hline & H. malabaricus & H. unitaeniatus & H. malabaricus & H. unitaeniatus \\
\hline $\mathrm{pH}$ & 8.0 & 8.0 & 10.0 & 9.5 \\
\hline Temperature ${ }^{\circ} \mathrm{C}$ & $>85$ & $>85$ & 35 & 50 \\
\hline \multicolumn{5}{|l|}{$\mathbf{K}_{\mathbf{m}}(\mathrm{mM})$} \\
\hline Ornithine & 0.47 & 1.08 & - & - \\
\hline Carbamoyl phosphate & 0.39 & 0.83 & - & - \\
\hline Ornithine $+\mathrm{Pi}$ & 0.55 & 1.16 & - & - \\
\hline Arginine & - & - & 4.35 & 3.84 \\
\hline
\end{tabular}



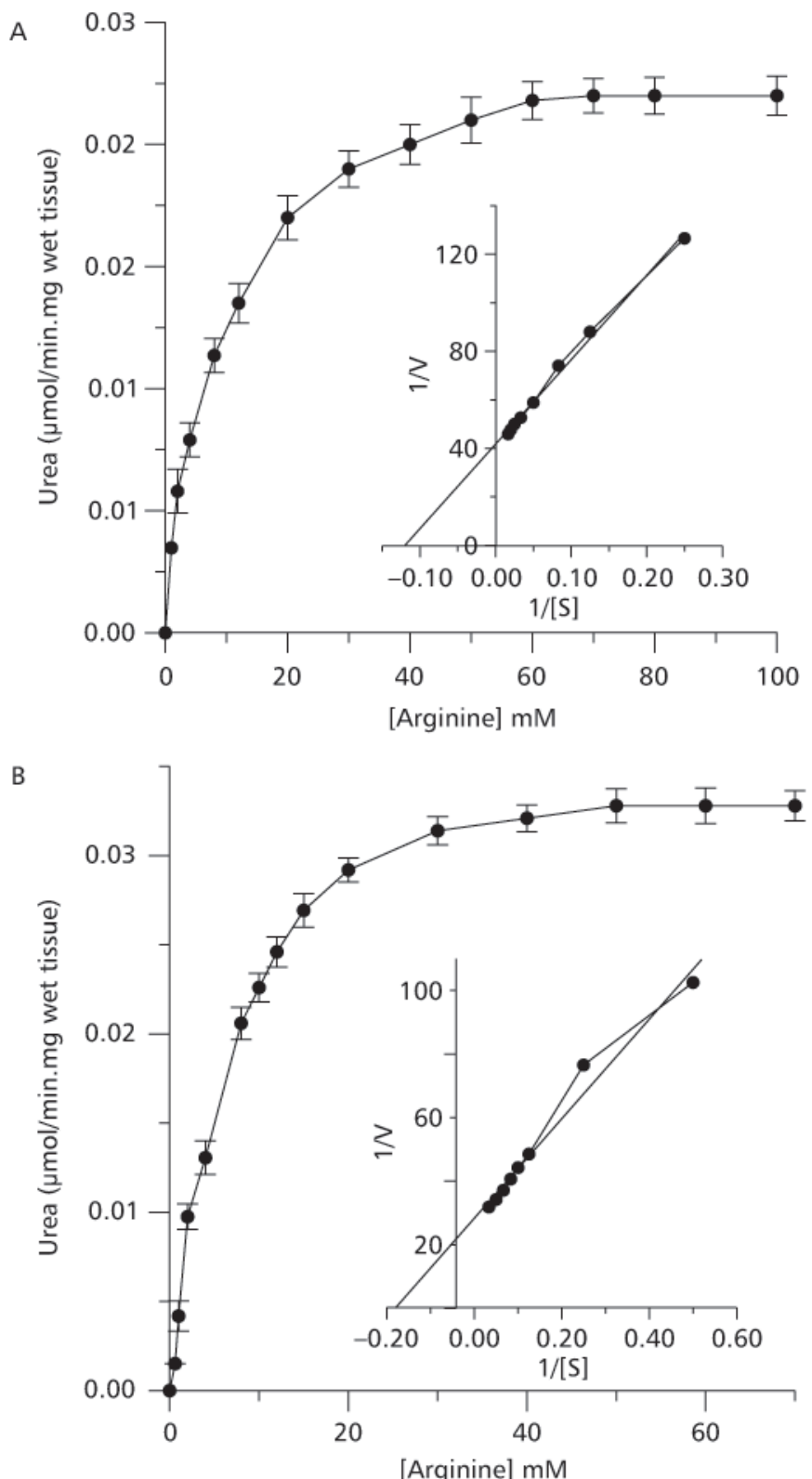

Fig. 1 - Substrate saturation curve of hepatic ARG of H. malabaricus (A) and H. unitaeniatus (B). The $\mathrm{K}$ values ware 4.35 $\mathrm{mM}(\mathrm{A})$ and $3.84 \mathrm{mM}(\mathrm{B})$. The data were derived from hepatic homogenate of fish from environmental $\mathrm{pH} 7.0$ (control). The $\mathrm{pH}$ reaction was 10.0 (A) and 9.5 (B) as previously optimized, and the incubation temperature was $25^{\circ} \mathrm{C}$. 

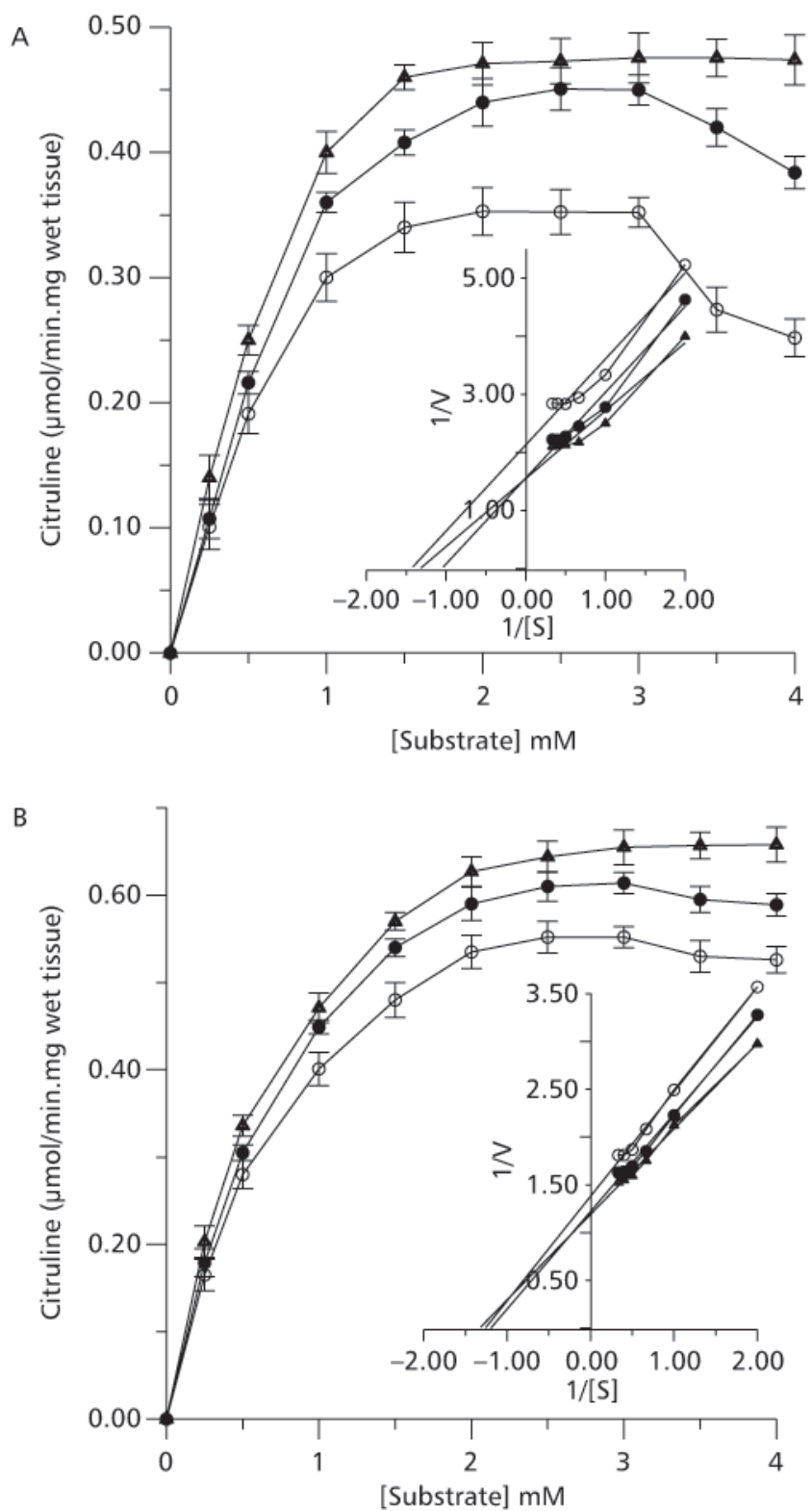

Fig. 2 - Substrate saturation curve of hepatic OCT from H. malabaricus (A) and H. unitaeniatus (B) and its phosphate inhibition curves. The $\mathrm{K}_{\mathrm{m}}$ values were: Fig. A, $\Delta$ carbamoyl phosphate $0.39 \mathrm{mM}, \bullet$ ornithine $0.47 \mathrm{mM}$; Fig. B, $\Delta$ carbamoyl phosphate $0.83 \mathrm{mM}$, $\bullet$ ornithine $1.08 \mathrm{mM}$. The OCT $\mathrm{Ki}_{\mathrm{s}}$ for inorganic phosphate $(\mathrm{Pi})$ were $\mathrm{O} 0.55 \mathrm{mM}(\mathrm{A})$ and $\mathrm{O} 1.16 \mathrm{mM}(\mathrm{B})$. The data were derived from hepatic homogenate of fish from environmental $\mathrm{pH} 7.0$ (control). The $\mathrm{pH}$ reaction was 8.0 for both assays as previously optimized, and the incubation temperature was $25^{\circ} \mathrm{C}$. 
TABLE 2

Specific activities of liver glutamine synthetase (GS), ornithine carbamoyl transferase (OCT), and arginine hydrolase (ARG) from $H$. malabaricus and $H$. unitaeniatus exposed to $1.0 \mathrm{mg} / \mathrm{L}$ ammonia. All values are expressed as means \pm SD.

\begin{tabular}{|c|c|c|c|c|}
\hline & \multicolumn{2}{|c|}{ H. malabaricus } & \multicolumn{2}{|c|}{ H. unitaeniatus } \\
\hline $\begin{array}{c}\text { OUC enzyme } \\
(\mu \mathrm{mol} / \mathrm{min} / \mathrm{mg} \text { of } \\
\text { wet tissue })\end{array}$ & Control & $\mathrm{NH}_{4}{ }^{+}$exposed & Control & $\mathrm{NH}_{4}{ }^{+}$exposed \\
\hline GS & $1.14 \pm 0.04$ & $2.43 * \pm 0.05$ & $1.43 \pm 0.05$ & $1.84 * \pm 0.04$ \\
\hline OCT & $0.81 \pm 0.02$ & $1.72 * \pm 0.03$ & $1.22 \pm 0.03$ & $1.27 \pm 0.02$ \\
\hline ARG & $3.15 \pm 0.12$ & $4.23 * \pm 0.23$ & $16.41 \pm 1.22$ & $17.11 \pm 1.53$ \\
\hline \multicolumn{5}{|c|}{ Plasma catabolite (mmol/L) } \\
\hline Ammonia & $0.95 \pm 0.03$ & $1.42 * \pm 0.02$ & $1.19 \pm 0.04$ & $1.98 * \pm 0.03$ \\
\hline Urea & $0.82 \pm 0.02$ & $1.53 * \pm 0.04$ & $0.50 \pm 0.03$ & $0.59 \pm 0.02$ \\
\hline
\end{tabular}

Values were compared by Mann Whitney Test and significant difference $(\mathrm{p}<0.05)$ between control versus exposed are marked by $(*)$.

However, in the presence of high ammonia levels, OCT activity may improve nitrogen excretion with efficiency being inversely related to $\mathrm{K}_{\mathrm{m}}$. The apparent $\mathrm{K}_{\mathrm{m}}$ obtained for jeju's OCT was twice that of traíra considering both substrates, ornithine and carbamoyl phosphate. These values, indicating different substrate affinities, suggest that ornithine catalysis toward urea was twice as fast in traíra if cellular concentration of ornithine was around 0.5 $\mathrm{mM}$. The cell ornithine concentration was not determined, however, considering the inhibitory effect of $3.5 \mathrm{mM}$ ornithine on both OCT, it is reasonable to suspect that the enzyme had a regulatory effect on urea synthesis. Inhibition of OCT by $10 \mathrm{mM}$ ornithine has been reported for teleost fish (De Gregório et al., 1993). The inhibitory effect of ornithine on OCT of jeju was less evident. These results agree with the distinct strategies we propose for ammonia detoxification in both species. Regulation of OCT by phosphate, the enzyme reaction product, is also indicative of adjustments in urea production in both species. However, traíra is more responsive to [Pi] than jeju.

Exposure of jeju and traíra to environmental ammonia resulted in different responses. Plasma ammonia in both species increased under ammonia exposure. This increase was slightly larger for jeju in which urea remained constant. The OUC enzymes OCT and ARG were unchanged but GS increased significantly. These results suggest that this species does not use urea synthesis strategy to reduce plasma ammonia. The tolerance concentration of blood ammonia ranges between $0.5-1.0 \mathrm{mmol} / \mathrm{L}$ for teleost (Wright, 1993). Compared to other fish species, jeju and traíra showed high blood ammonia and the exposure to $1.0 \mathrm{mg} / \mathrm{L}$ of environmental ammonia increased those values. The arctic char (Salvelinus alpinus) shows flaccid paralysis as plasma ammonia reaches $2.0 \mathrm{mmol} / \mathrm{L}$ (Lumsden et al., 1993), nevertheless the air-breathing teleost Heteropneustes fossilis can tolerate the unusually high concentration of $4.0 \mathrm{mmol} / \mathrm{L}$. The experimental ammonia concentration $(1.0 \mathrm{mg} / \mathrm{L})$ used in the present work did not cause death or behavioral disorders in traíra. However, a remarkable activity level was observed for jeju. The exposure time could have been insufficient to observe further effects, but biochemical changes were observed. The significant increase of the inducible enzyme GS seems to be a way to minimize the ammonia toxicity in jeju other than urea synthesis. The synthesis of glutamine as a chemical compound to hide the free ammonia for posterior excretion by glutaminase activity should be the strategy used by jeju. A distinct one was clearly observed for traíra. The increase of OUC enzymes $(p<0.05)$ and the plasma urea concentration $(60$ percent higher than jeju) are solid evidence that urea synthesis is the choice to detoxify the blood ammonia. The metabolic outlines of jeju and traíra in response to external ammonia increase permit one to assume that both species, although they are very evolutionary close and living in the same environment, present 
different biochemical responses to the same aggressor. These different biochemical aptitudes should partially explain why traíra is able to survive for long periods in mud during dry seasons, while jeju snakes quickly over the grass looking for new water ponds.

Acknowledgments - The authors thank to Dr. M. A. Del Lama from Dept. of Genetics and Evolution, UFSCar, for his suggestions, and Alexandre E. Altran for his technical support. This paper was adapted from the thesis submitted by Vera Perussi Polez to the Federal University of São Carlos, UFSCar, in partial fulfillment of the requirements for a doctoral degree. This research was funded by Conselho Nacional de Desenvolvimento Científico e Tecnológico (CNPq), Fundação de Amparo à Pesquisa do Estado de São Paulo (Fapesp), and Conselho de Aperfeiçoamento do Ensino Superior (Capes).

\section{REFERENCES}

ALABASTER, J. S. \& LLOYD, R., 1980, Water quality criteria for freshwater fish. Butter-Worth, London, pp. 297-365.

BOYDE, T. C. \& RAHMATULLAH, M., 1980, Optimization of conditions of the colorimetric determination of citrulline, using diacetyl monoxime. Analyt. Biochem., 107: 424-431.

CVANCARA, V. A., 1969, Studies on tissues arginase and ureogenesis in freshwater teleosts. Comparative Biochemistry and Physiology, 30: 489-496.

DABROWSKA, H. \& WLASOW, T., 1986, Sublethal effect of ammonia on certain biochemical and hematological indicators in common carp. Comparative Biochemistry and Physiology., 83C: 179-184.

DE GREGÓRIO, A., VAlENTINI, G., BELlOCCO, E., DESIDERI, A. \& CUZZOCREA, G., 1993, A comparative study on liver ornithine carbamoyl transferase from a marine mammal Stenella and an elasmobranch Sphyrna zygaena. Comparative Biochemistry and Physiology, 105B: 497-501.

EMERSON, K., RUSSO, R. C., LUND, R. E. \& THURSON, R. V., 1975, Aqueous ammonia equilibrium calculations. Effect of $\mathrm{pH}$ and temperature. Journal of Fish Research Board. Canada., 32: 2379-2383.

GENTZKOW, C. J. \& MASEN, J. M., 1942, An accurate method for the determination of blood urea nitrogen by direct nesslerization. Journal of Biological Chemistry, 143: 531-544.

GODOY, M. P., 1975, Peixes do Brasil-Subordem OstariophysiBacia do Rio Mogi-Guaçu. Editora Franciscana, Piracicaba, São Paulo.

HENRY, R. J., SOBEL, C. \& KIM, J., 1957, A modified carbonate-phosphotungstate method for the determination of uric acid and comparison with the spectrophotometric uricase method. Am. J. Clin. Pathol., 282: 152-160.

HOCHACHKA, P. W. \& SOMERO, G. N., 1973, Strategies of biochemical adaptations. W.B. Saundrs, Philadelphia, USA, p. 385.

HOCHACHKA, P. W. \& SOMERO, G. N., 1984, Biochemical adaptations. Princeton University Press, USA, p. 355.

LUMSDEN, J. S., DERKSEN, J., BYRNE, P. J. \& FERGUSON,
H. W., 1993, Paralysis in farmed Arctic char Salvelinus alpinus associated with ammonia toxicity. Veterinary Record, 133: 422-423.

McKENZIE, D. J., PIRACCINI, G., FELSKIE, A., ROMANO, P., BRONZI, P. \& BOLIS, C. L., 1999, Effects of plasma total ammonia content and $\mathrm{pH}$ on urea excretion in Nile tilapia. Phyisiological and Biochemical Zoology, 721: 116-125.

MOMMSEN, T. P. \& WALSH, P. J., 1989, Evolution of urea synthesis in vertebrates: the piscine connection. Science, 243: 72-75.

MOMMSEN, T. P. \& WALSH, P. J., 1992, Biochemical and environmental perspectives on nitrogen metabolism. Experientia, 48: 583-93.

NELSON, J. S., 1984, Fishes of the world. Wiley Interscience Publication John and Sons, London, p. 320.

OLSON, K. R. \& FROMM, P. O., 1971, Excretion of urea by two teleosts exposed to different concentrations of ambient ammonia. Comparative Biochemitry and Physiology, 40A: 999-1007.

POLEZ, V. L. P., MONZANI, P. S. \& MORAES, G., 1998, Comparison of glutamine synthetase, carbamoyl phosphate synthetase and arginase from freshwater fish Hoplias malabaricus, Hoplias lacerdae and Hoplerythrinus unitaeniatus: enzyme compartimentalization. Journal of Comparative Biology, 3(2): 185-190.

RAHMATULLAH, D. F. \& BOYDE, T. R. C., 1980, Improvements in the determination of urea using diacetyl monoxime methods with and without deproteinization. Clinica Chimica Acta, 107: 3-9.

SMART, G., 1976, The effect of ammonia exposure on gill structure of the rainbow trout. Journal of Fish Biology, 8: 471-479.

SPOTTE, S. \& ANDERSON, G., 1989, Plasma cortisol changes in seawater-adapted mummichogs Fundulus heterocletus exposed to ammonia. Canadian Fisheries of Aquatic Science, 46: 2065.

TOMASSO, J. R., DAVIS, K. B. \& SIMCO, B. A., 1981, Plasma corticosteroid dynamics in channel catfish (Ictalurus punctatus) exposed to ammonia and nitrite. Canadian Fisheries of Aquatic Science, 38: 1105-1112.

VAL, A. L. \& ALMEIDA-VAL, V. M. F., 1995, Fishes of the Amazon and their Environment. Physiological and Biochemical Aspects. Springer-Verlag, pp. 70-180.

VORHABEN, J. E., WONG, L. \& CAMPBELL, J. W., 1973, Assay for glutamine synthetase activity. Biochemical Journal, 135: 893-896.

WALSH, P. J., 1997, Evolution and regulation of urea synthesis and ureotely in Batrachoidid fishes. A Review of Physiol., 59: 299-323.

WRIGHT, P. A., 1993, Nitrogen excretion and enzyme pathaways for ureagenesis in freshwater tilápica Oreochromis niloticus. Physiological Zoology, 66: 881-901.

WRIGHT, P. A., 1995, Review: Nitrogen excretion: three end products, many physiological roles. Journal of Experimental Biology, 198: 273-281. 